\title{
First record of the Pale-faced Bat Phylloderma stenops Peters, 1865 (Chiroptera: Phyllostomidae) in the province of Guayas, southwestern Ecuador
}

\author{
Jaime A. Salas ${ }^{1,3 *}$, Santiago F. Burneo ${ }^{2}$, Fabián Viteri H. ${ }^{1}$, and Raúl Carvajal M. ${ }^{1}$ \\ 1 Gobierno Autónomo Descentralizado Provincial del Guayas-Dirección de Gestión Ambiental Illingworth108 y Malecón Simón Bolívar. Guayaquil, \\ Ecuador. \\ 2 Sección Mastozoología del Museo de Zoología, Pontificia Universidad Católica del Ecuador. Av. 12 de Octubre y Roca. Quito, Ecuador \\ 3 Universidad de Guayaquil, Facultad de Ciencias Naturales, Escuela de Biología. Av. Raúl Gómez Lince s/n y Av. Juan Tanca Marengo. \\ * Corresponding author. E-mail: salaszjaime@hotmail.com
}

\begin{abstract}
We report the first record of Phylloderma stenops in the province of Guayas, Ecuador. The specimen was captured in a heavily disturbed area, surrounded by small remnants of semi-deciduous lowland forests. We also present a predictive distribution map, constructed with the new and existing information for P. stenops in Ecuador and other countries in South America, showing that this species may occur in other areas where it has not yet been observed.
\end{abstract}

DOI: $10.15560 / 10.5 .1218$

Phylloderma stenops Peters, 1865 is a large bat with robust body, white wingtips, large and narrow muzzle, broad and lance-shaped nose leaf, and reddish-brown dorsal hairs with pale base and an often slightly bright terminal band (Goodwin 1942; LaVal and Rodríguez-H. 2002; Tirira 2007; Medellín et al. 2008; Díaz et al. 2011). Currently, three subspecies are recognized (Simmons 2005; Gardner 2008): P. s. septentrionalis Goodwin, 1940, which occurs in Central America, from southern Mexico to Belize (Goodwin 1942, 1946; LaVal and Rodríguez-H. 2002; Cruz-Lara et al. 2004; Medellín et al. 2008; Reid 2009); P. S. stenops Peters, 1865, recorded in several countries of northern South America, such as Trinidad and Tobago, Venezuela, Colombia, Ecuador, and the northwest and southern regions of Peru (Goodwin and Greenhall 1964; Handley 1976; Sánchez and Rivas 1993; Ascorra et al. 1991, 1993; Tirira 2007; Williams and Genoways 2008), extending into the Amazon Basin and southeastern Brazil (Sampaio et al. 2003; Esbérard and Faria 2006; Williams and Genoways 2008); and P. s. boliviensis Barquez \& Ojeda, 1979, endemic to Bolivia (Anderson 1997; Acosta and Aguanta 2006; Díaz et al. 2011). In Ecuador, P. stenops was reported in 1998, in a meeting abstract by I. Castro and L. Novilos, but the first published reference was provided by Albuja and Mena-V. (2004), and it has been reported in the coastal (lowland evergreen forests, inundated floodplain forests, deciduous forests) and Amazonian regions (mostly evergreen forests), but not in the inter-Andean region (Tirira 1999, 2007, 2008; Albuja and Mena-V. 2004; Trujillo and Albuja 2005; Carrera et al. 2010; Table 1).

On 7 October 2010, we conducted a survey of the fauna on the grounds of El Retiro Ranch, near the Pucón River $\left(01^{\circ} 18^{\prime} 41.7^{\prime \prime} \mathrm{S}, 79^{\circ} 56^{\prime} 33.4^{\prime \prime} \mathrm{W}, 40 \mathrm{~m}\right.$ above sea level), Chicompe sector, Balzar locality, Guayas provinceEcuador. This ranch is characterized by the presence of livestock and silvopasture systems, and it is surrounded by small remnants of semi-deciduous lowland forests (Ministerio del Ambiente de Ecuador 2013). The predominant native plants observed in these remnants during the survey were Spondias mombim, Phytelephas aequatorialis, Cochlospermum vitifolium, Cordia alliodora, Capparis spp., Albizia multiflora, Centrolobium ochroxylum, Pseudosamanea guachapele, Machaerium millei, Ficus obtusifolia, Muntingia calabura, Piper spp., Sapindus saponaria, Chrysophyllum argenteum, Guazuma ulmifolia, Trema micrantha, and Vitex gigantea; the predominant species close to the river were Albizia saman and Erythrina edulis.

Trapping was conducted for one night, using two mist nets of $6 \times 2.5 \mathrm{~m}$ each. These nets were placed above the river, from 18:00 h until approximately 06:00 h (following Kunz et al. 1996). Bats were identified according to the guidelines detailed in Albuja (1999) and Tirira (2007). In the case of $P$. stenops, in order to achieve identification to the subspecies level, we also analyzed specimens from eastern and western Ecuador deposited at the Mammalogy Division of the Museo de Zoología at the Pontificia Universidad Católica del Ecuador-QCAZ. Specimens from El Retiro Ranch were collected under Permit No. 001-10 IC-FAU-DNB/MA, issued by the Ministerio del Ambiente of Ecuador.

We captured one female $P$. stenops (QCAZ 12651; Figure 1, Table 1), presenting the following external measurements (in $\mathrm{mm}$ ): total length, 95.8; tail length, 12.4; hind foot length, 28.1; ear length, 21.1; forearm length, 64.1; tragus, 9. Cranial measurements (following Barquez and Ojeda 1979) are close to those described for the subspecies P. s. stenops (Barquez and Ojeda 1979; Table 2 ), which is in agreement with Williams and Genoways (2008), who assigned this subspecies to Ecuador. The analysis of a larger sample, however, is necessary to validate this identification at the subspecies level. Other 
bat species captured during fieldwork by mist netting were Carollia brevicauda (Schinz, 1821), Artibeus fraterculus Anthony, 1924, and Phyllostomus discolor (Wagner, 1843); Molossus molossus (Pallas, 1766) and Eptesicus innoxius (Gervais, 1841) were found in shelters under the bark of an $A$. saman tree.

Previous records of $P$. stenops in Ecuador were obtained from protected natural areas (e.g., Limoncocha Biological Reserve, Yasuní National Park, and Cuyabeno Wildlife Reserve, in the Amazonian region; and La Chiquita Wildlife Refuge, Río Palenque Protected Forest, and Puyango Petrified Forest, in western Ecuador) or in disturbed areas such as banana plantations (Table 1). The previous locations in protected areas contrast with our record, which was located in a place heavily disrupted by livestock, with small remnants of riparian vegetation. Emmons and Feer (1997), however, reported that this species is found around streams and swamps or marshes, which coincides with our findings. Phylloderma stenops roosts in caves (Trajano 1982; Bredt et al. 1999; Esbérard et al. 2005) and feeds on fruit pulp, insects, and even small vertebrates (e.g., a large rat, apparently a Proechimys) (Jeanne 1970; LaVal 1977; Esbérard and Faria 2006; York 2008; Sampaio et al. 2008), resources that might be available at the forest remnants around El Retiro Ranch.

Phylloderma stenops is a rare species in Ecuador (Reid et al. 2000; Albuja and Mena-V. 2004; Trujillo and Albuja 2005; Carrera et al. 2010; Brito and Arguero 2012) and other South American countries (Ascorra et al. 1991, 1993; Sánchez and Rivas 1993; Bredt et al. 1999; Sampaio et al. 2003; Acosta and Aguanta 2006), with no previous record from Guayas Province or in semi-deciduous forests (Parker and Carr 1992; Rodríguez et al. 1995; Albuja 1982, 1999; Albuja and Mena-V. 2004; Trujillo and Albuja 2005; Tirira 2007, 2008; Salas 2008). Recent records that have been published for this species are from other locations in southwestern Ecuador, specifically in Puyango, in the El Oro Province (Carrera et al. 2010), and in the Amazonian Region, specifically from the Morona Santiago and Zamora Chinchipe provinces (Brito and Arguero 2012).

In recent years, there have been new records and extensions in the distribution of various species of bats in Southwestern Ecuador (Salas 2008; Carrera et al. 2010, Narváez et al. 2012; Tirira et al. 2012a, b; Salas et al. 2013), despite the rapid deterioration of its vegetation cover and expected loss of biodiversity (Dobson and Gentry 1991; Ministerio de Ambiente de Ecuador 2013). This region should be considered a priority for bat research and conservation programs, both in protected and unprotected forest areas. Although the occurrence of P. stenops in Guayas Province was predicted by Williams and Genoways (2008), the predictive distribution map presented for this species by Tirira (2007) restricted its occurrence to the northwestern rainforests and Amazonia.

Using data from museum specimens collected in Ecuador, Colombia, and Peru (Table 3), a predictive distribution model was generated using a Maximum Entropy approach (MaxEnt; Phillips et al. 2006). Eight replications of the model were run separating $15 \%$ of the occurrences in a test set for evaluation purposes by measuring the area under the ROC curve (AUC) in each evaluation set. The mean AUC for the model replications was $0.789(\mathrm{SD}=0.156)$. The model predicts the distribution for $P$. stenops in protected areas where this bat has not yet been observed, as the Protected Forests as ChillanesBucay, Molleturo-Mollepongo, Cerro Blanco, or Isla Santay Recreation National Area in Guayas Province (Figure 2).

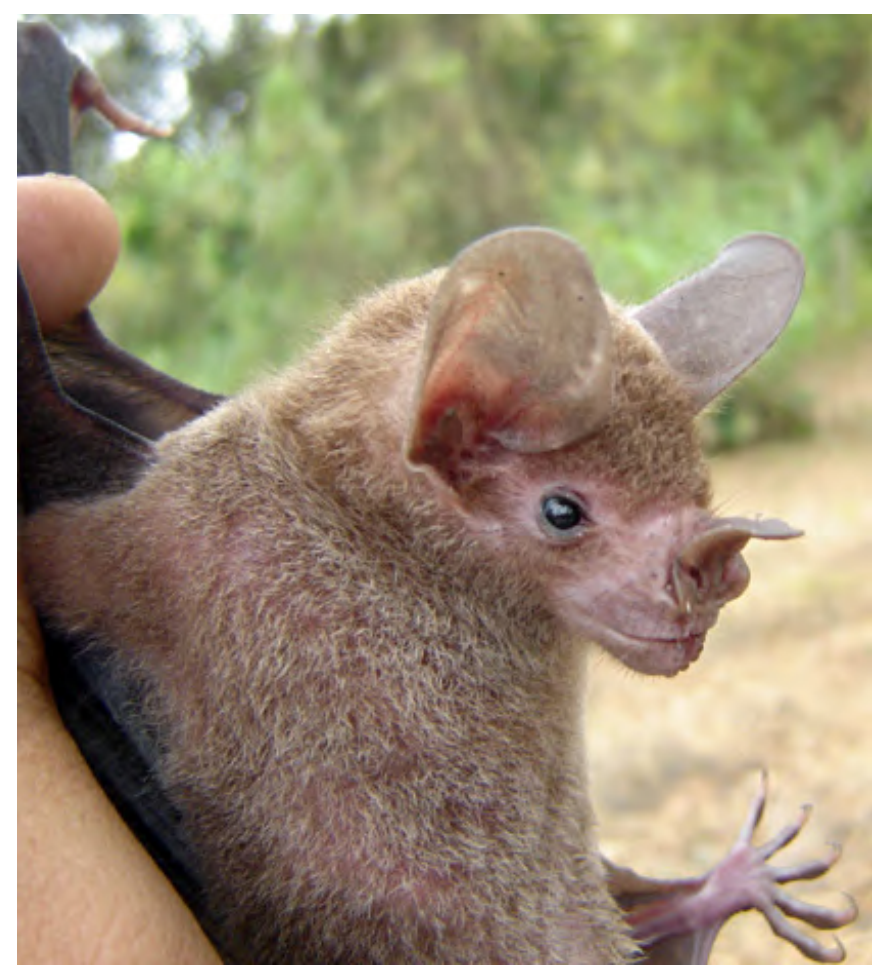

FigurE 1. Pale-Faced Bat Phylloderma stenops (QCAZ 12651, †) captured in the Pucón River area (Guayas Province-Ecuador). Photo by Jaime Salas.

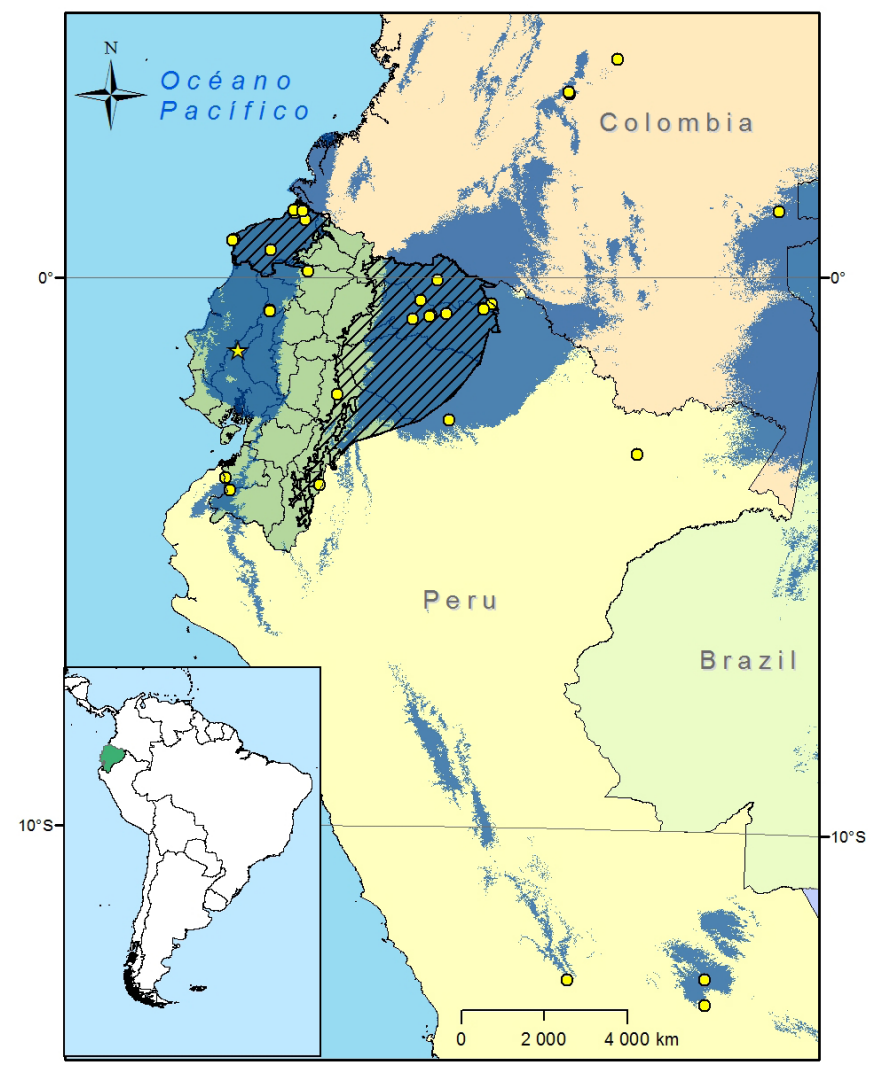

Figure 2. Distribution of Phylloderma stenops in Ecuador. Black lines represent the current distribution as reported by Tirira (2007). The blue-shaded area represents the predictive distribution model proposed for Ecuador. Yellow dots represent known records with registered geographic coordinates. The yellow star represents our record near the town of Balzar. 
The climatic envelope that the model predicted for this species included an annual mean temperature of $25.2^{\circ} \mathrm{C}( \pm$ $0.91)$ and a mean annual rainfall of $2,846 \mathrm{~mm}( \pm 617)$. The temperature at the new location reported here $\left(25.6^{\circ} \mathrm{C}\right)$ is consistent with the predictions of the model. However, the model's prediction for precipitation is higher than the annual average of the new location $(1,306 \mathrm{~m})$, although this value is within the range of the model's precipitation (328-5,016 mm), which suggests that this location is likely near the edge of the climatic envelope. Also, four bioclimatic variables explained $55 \%$ of the variation seen in the model: the precipitation of the warmest quarter $(15.2 \%$, model average: $686.2 \mathrm{~mm} \pm 217$; new locality $879 \mathrm{~mm})$, maximum temperature of warmest month $(13.6 \%$, model

TABLE 1. Annotated list of records of the Pale-faced Bat Phylloderma stenops in Ecuador.

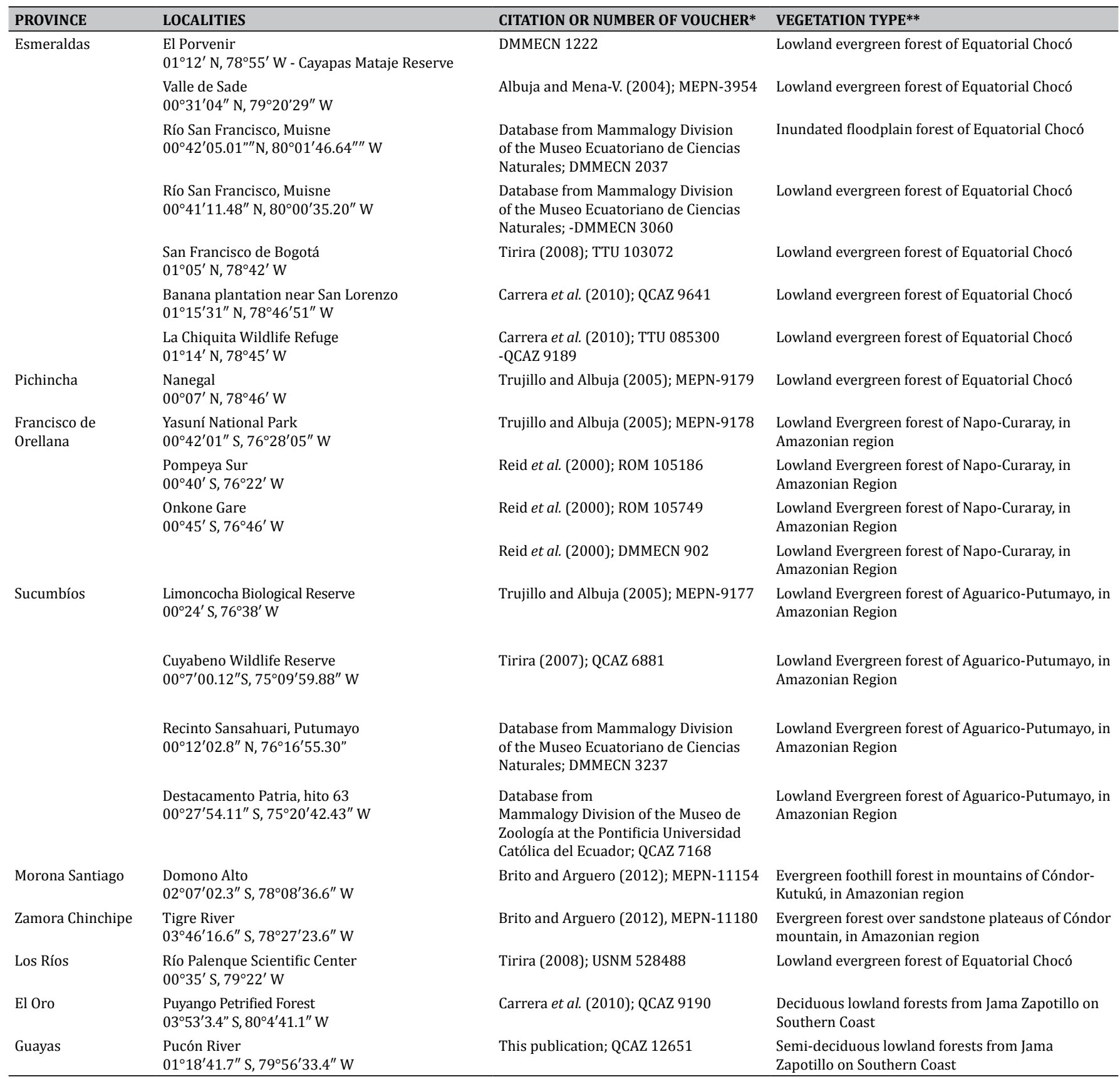

* Full collection names with acronyms are presented in Table 3.

** Ministerio del Ambiente del Ecuador. 2013. Sistema de Clasificación de los Ecosistemas del Ecuador Continental. Quito: Subsecretaría de Patrimonio Natural. 232 pp.

TABLE 2. Cranial measurements ( $\mathrm{mm}$ ) taken from specimens of Phylloderma stenops in eastern and western Ecuador.

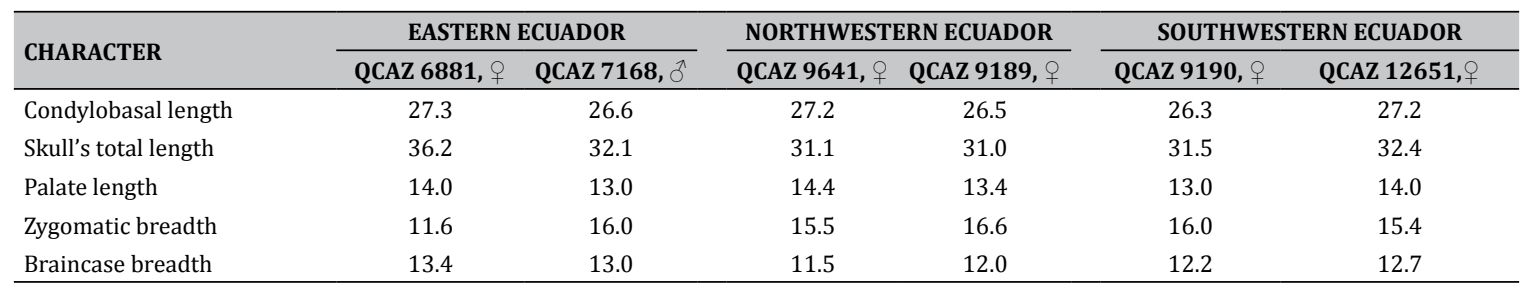


TABLE 3. Number of specimens used in the predictive niche modeling retrieved and verified using Red Noctilio* and Global Biodiversity Information Facility (GBIF, www.gbif.org)

\begin{tabular}{llc}
\hline ACRONYM & MUSEUM & SPECIMENS \\
\hline EPN & Museo Gustavo Orcés, Escuela Politécnica Nacional, Quito & 4 \\
FMNH & Field Museum of Natural History, Chicago, IL & 3 \\
ICN & Instituto de Ciencias Naturales, Museo de Historia Natural, Bogotá & 5 \\
KU & University of Kansas Natural History Museum, Lawrence, KS & 2 \\
LSUMZ & Louisiana State University, Museum of Zoology, Baton Rouge, LA & 2 \\
DMMECN & División de Mastozoología - Museo Ecuatoriano de Ciencias Naturales, Quito & 4 \\
QCAZ & Museo de Zoología, Pontificia Universidad Católica del Ecuador, Quito & 6 \\
ROM & Royal Ontario Museum, Toronto, ON & 3 \\
TTU & The Museum, Texas Tech University, Lubbock, TX & 4 \\
USNM & United States National Museum, Smithsonian Institution, Washington, DC & 1 \\
\hline
\end{tabular}

*1995-2013 unpublished database on the mammals from Ecuador compiled by D. Tirira.

average: $30.9^{\circ} \mathrm{C} \pm 0.8$; new locality $31.6^{\circ} \mathrm{C}$ ), temperature annual range $\left(13.5 \%\right.$, model average: $11.1^{\circ} \mathrm{C} \pm 1.3$; new locality $12.3^{\circ} \mathrm{C}$ ), and mean monthly temperature range $\left(12.5 \%\right.$, model average: $9.4^{\circ} \mathrm{C} \pm 1.0$; new locality $\left.10.1^{\circ} \mathrm{C}\right)$. These values also support the occurrence of $P$. stenops in transitional areas between deciduous and humid tropical, depicting a different scenario from those predicted for other phyllostomines based on a similar methodology (Narváez et al. 2012; Tirira et al. 2012a).

ACKNOWLEDGEMENTS: This fieldwork was performed according to the framework of the Strategic Planning of the Provincial System of Conservation Areas, with the goal of identifying new priority locations for conservation efforts in the Guayas Province-Ecuador. We thank Burton Lim, Rubén Bárquez, Pablo Moreno, and Julio César Bracamonte for the literature provided; to Juan Pablo Carrera, Paul Velazco, Marcelo Nogueira and the two anonymous reviewers for theirs valuable comments on the manuscript; to Ma. Alejandra Camacho for allow us checking the P. stenops' vouchers from QCAZ collection, and Leonardo Álava for his assistance in checking the P. stenops' vouchers in the QCAZ museum; to Diego Tirira, Jorge Brito and Juan Pablo Carrera for providing the numbers of $P$. stenops' vouchers from their database, and finally to our coworkers Geovanny Zambrano and Carola Bohórquez for their assistance in the field. We want to give special thanks to Joy Collins for her valuable help in the review the English language in this article.

\section{Literature Cited}

Acosta, L. and F. Aguanta. 2006. Preliminary List of Mammals from the Experimental Forest Elías Meneses, Santa Cruz, Bolivia. Kempffiana 2(1): 144-149 (http://museonoelkempff.org/sitio/Informacion/ KEMPFFIANA/Kempffiana\%202(1)/144-149.pdf).

Albuja, L. 1982. Murciélagos del Ecuador. (1 $1^{\text {st }}$ ed.). Quito: Escuela Politécnica Nacional. Departamento de Ciencias Biológicas. 285 pp.

Albuja, L. 1999. Murciélagos del Ecuador. (2 ${ }^{\text {nd }}$ ed.). Quito: Escuela Politécnica Nacional. Departamento de Ciencias Biológicas. 288 pp.

Albuja, L. and P. Mena-V. 2004. Quirópteros de los bosques húmedos del occidente del Ecuador. Politécnica 25(1): 19-96 (http://bibdigital. epn.edu.ec/bitstream/15000/4744/3/Quiropteros Occidente 2004 Biologia5 .pdf).

Anderson, S. 1997. Mammals of Bolivia, taxonomy and distribution. Bulletin of the American Museum of Natural History 231: 1-652 (http://digitallibrary.amnh.org/dspace/handle/2246/1620).

Ascorra, C.F., D.E. Wilson and M. Romo. 1991. Lista anotada de los quirópteros del Parque Nacional Manu, Perú. Publicaciones del Museo de Historia Natural. Universidad Nacional Mayor de San Marcos (A) 42: 1-14 (http://museohn.unmsm.edu.pe/publizoo/publizoo42.htm).

Ascorra, C.F., D.L. Gorchov and F. Cornejo. 1993. The bats from Jenaro Herrera, Loreto, Perú. Mammalia 57(4): 533-552 (doi: 10.1515/ mamm.1993.57.4.533).

Bárquez, R.M., and R.A. Ojeda. 1979. Nueva subespecie de Phylloderma stenops (Chiroptera Phyllostomidae). Neotrópica 25(73):83-89 (https://www. researchgate.net/publication/259475671_Nueva_subespecie_de_ Phylloderma_stenops_(Chiroptera_-_Phyllostomidae)?ev=srch_pub).

Bredt, A., W. Uieda and E.D. Magalhaes. 1999. Morcegos cavernícolas da região do Distrito Federal, centro-oeste do Brasil (Mammalia, Chiroptera). Revista Brasileira de Zoologia 16(3): 731-770 (http:// www.scielo.br/pdf/rbzool/v16n3/v16n3a12).

Brito J. and A. Arguero. 2012. Nuevos datos sobre la distribución de Scolomys ucayalensis (Rondentia: Cricetidae) y Phylloderma stenops (Chiroptera: Phyllostomidae) en Ecuador. Mastozoología Neotropical 19(2): 293-298 (http://www.sarem.org.ar/wp-content/ uploads/2013/06/SAREM_MastNeotrop_19-2_08_Brito.pdf).

Carrera, J.P., S. Solari, P.A. Larsen, D.F. Alvarado-Serrano, A.D. Brown, C.B. Carrión and J.S. Tello. 2010. Bats of the tropical lowlands of Western Ecuador. Special Publications, Museum of Texas Tech University 57: 1-37 (http://www.nsrl.ttu.edu/publications/specpubs/sps/SP57.pdf).

Cruz-Lara, L.E., C. Lorenzo, L. Soto, E. Naranjo and N. Ramírez-Marcial. 2004. Diversidad de mamíferos en cafetales y selva mediana de las cañadas de la selva Lacandona, Chiapas, México. Acta Zoológica Mexicana 20(1): 63-81 (http://www.redalyc.org/pdf/575/57520106.pdf).

Díaz, M.M., L.F. Aguirre and R.M. Bárquez. 2011. Clave de identificación de los murciélagos del cono sur de Sudamérica. Cochabamba, Bolivia: Centro de Estudios en Biología Teórica y Aplicada. 94 pp.

Emmons, L.H. and F. Feer. 1997. Neotropical rainforest mammals: a field guide. ( $2^{\text {nd }}$ ed.). Chicago: Chicago Univesity Press. 307 pp.

Esbérard, C.E.L., J.A. Mota and C. Perigro. 2005. Morcegos cavernícolas da APA Nascentes do Rio Vermelho, Goiás. Revista brasileira de Zoociências 7(2): 311-325 (https://www.academia.edu/1212984/Morcegos_da_ Area_de_Protecao_Ambiental_do_Rio_Vermelho_Goias).

Esbérard, C.E.L. and D. Faria. 2006. Novos registros de Phylloderma stenops Peters, na Mata Atlântica, Brasil (Chiroptera, Phyllostomidae). Biota Neotropica 6(2): 1-5 (http://www.redalyc.org/pdf/1991/ 199114291025.pdf)

Gardner, A.L. (ed.) 2008 [2007]. Mammals of South America: Volume I. Marsupials, Xenarthrans, Shrews, and Bats. Chicago and London: University of Chicago Press. 690 pp.

Goodwin, G.G. 1942. Mammals of Honduras. Bulletin of the American Museum of Natural History 79(2): 107-195 (http://digitallibrary.amnh.org/ dspace/handle/2246/986).

Goodwin, G.G. 1946. Mammals of Costa Rica. Bulletin of the American Museum of Natural History 87(5): 271-473 (http://digitallibrary. amnh.org/dspace/handle/2246/316).

Goodwin, G.G. and A.M. Greenhall. 1964. New records of bats from Trinidad and comments on the status of Molossus trinitatus Goodwin. American Museum Novitates 2195: 1-23 (http://digitallibrary.amnh. org/dspace/handle/2246/1270).

Handley, C.O. Jr. 1976. Mammals of the Smithsonian Venezuelan Project. Brigham Young Brigham Young University Science Bulletin, Biological Series 20(5): 1-89 (https://ojs.lib.byu.edu/spc/index. php/BYUSciBullBioS/article/viewFile/30679/29161).

Kunz, T.H., C. Tidemann and G.C. Richards. 1996. Capturing small volant mammals; pp. 122-146, in: D.E. Wilson, F.R. Cole, J.D. Nichols, R. Rudran and M.S. Foster (ed.). Measuring and Monitoring Biological Diversity. Standard Methods for Mammals. Washington, D.C.: Smithsonian Institution Press.

Jeanne, R.L. 1970. Note on a Bat (Phylloderma stenops) preying upon the brood of a social wasp. Journal of Mammalogy 51(3): 624-625 (doi: 10.2307/1378408).

LaVal, R.K. 1977. Notes on some Costa Rican bats. Brenesia 10-11: 77-83 (http://biblioteca.museocostarica.go.cr/articulo.aspx?id=2925\& art=8698).

LaVal, R.K. and B. Rodríguez-H. 2002. Murciélagos de Costa Rica. Santo Domingo de Heredia: Instituto Nacional de Biodiversidad INBio. 320 pp.

Ministerio del Ambiente del Ecuador. 2013. Sistema de Clasificación de los Ecosistemas del Ecuador Continental. Quito: Subsecretaría de Patrimonio Natural. 232 pp. 
Medellín, R.A., H.T. Arita and O. Sánchez. 2008. Identificación de los murciélagos de México. Clave de campo. ( $2^{\text {nd }}$ ed.). México D.F.: Instituto de Ecología, UNAM-CONABIO. 89 pp.

Narváez C.A., M.V. Salazar, D.G. Tirira and S.F. Burneo. 2012. Extensión de la distribución de Vampyrum spectrum (Linnaeus, 1758) (Chiroptera, Phyllostomidae) para el Suroccidente de Ecuador; pp. 201-208, in: D.G. Tirira and S.F. Burneo (eds.). Investigación y Conservación sobre Murciélagos en el Ecuador. Publicación especial sobre los mamíferos del Ecuador 9. Quito: Pontificia Universidad Católica del Ecuador Fundación Mamíferos y Conservación and Asociación Ecuatoriana de Mastozoología.

Parker, T.A. III, and J.L. Carr (eds.). 1992. Status of Forest Remnants in the Cordillera de la Costa and Adjacent of Southwestern Ecuador. Washington: Conservation International. Rap Working Papers 2. 172 pp (http://www.conservation.org/Documents/RAP_Reports/ RAP02_Cordillera_Costa_Ecuador_Oct-1992.pdf).

Phillips, S.J., R.P. Anderson and R.E. Schapire. 2006. Maximum entropy modeling of species geographic distributions. Ecological Modelling 190: 231-259 (doi:10.1016/j.ecolmodel.2005.03.026).

Reid, F. 2009. A Field Guide to the Mammals of Central America and Southeast Mexico. ( $2^{\text {nd }}$ ed.) US: Oxford University Press. 346 pp.

Reid, F.A., M.D. Engstrom and B.K. Lim. 2000. Noteworthy records of bats from Ecuador. Acta Chiropterologica 2(1): 37-51.

Rodríguez, F., M. Larrea, A. Ruíz, V. Benítez, F. Nogales, P. Suárez, I. Jaramillo and P. Guerrero (eds). 1995. Caracterización Ecológica y Socio-Económica de la Isla Santay, Guayas, Ecuador. Quito: Ecociencia. $115 \mathrm{pp}$.

Salas, J. 2008. Murciélagos del Bosque Protector Cerro Blanco. Chiroptera Neotropical 14(2): 397-402 (https://chiroptera.unb.br/index.php/ cn/article/view/97).

Salas, J.A., F. Viteri H., M. Zambrano M., V. Benavides H. and R. Carvajal M. 2013. Distribution extension of Proboscis Bat Rhynchonycteris naso (Wied-Neuwied, 1820) (Chiroptera: Emballonuridae): New record for southwestern Ecuador. Check List 9(5): 1054-1056 (http://www. checklist.org.br/getpdf?NGD275-12).

Sampaio E.M., E.K.V. Kalko, E. Bernard, B. Rodríguez-Herrera and C.O. Handley-Jr. 2003. A biodiversity Assessment of Bats (Chiroptera) in a Tropical Lowland Rainforest of Central Amazonia, including methodological and conservation considerations. Studies on Neotropical Fauna and Environment 38(1): 17-31 (doi: 10.1076/ snfe.38.1.17.14035).

Sampaio, E., B. Lim, S. Peters and J. Arroyo-Cabrales. 2008. Phylloderma stenops; in: IUCN 2012. IUCN Red List of Threatened Species. Version 2012.2. Accessible at http://www.iucnredlist.org/. Captured on 03 May 2013.

Sánchez-Palomino, P. and P. Rivas-Pava. 1993. Composición, abundancia y riqueza de especies de la comunidad de murciélagos en bosques de galería en la Serranía de La Macarena (Meta-Colombia). Caldasia 17(2): 301-312 (doi: 10.15446/caldasia)
Simmons, N.B. 2005. Order Chiroptera; pp. 312-529, in: D.E Wilson and D.M. Reeder (eds.). 2005. Mammal Species of the World. A Taxonomic and Geographic Reference, $3^{\text {rd }}$ edition. Baltimore: Johns Hopkins University Press.

Tirira, D. 1999. Mamíferos del Ecuador. Quito: Museo de Zoología. Centro de Biodiversidad y Ambiente. Pontificia Universidad Católica del Ecuador/ Simbioe. Publicación Especial 2. 374 pp.

Tirira, D. 2007. Guía de Campo de los Mamíferos del Ecuador. Ediciones Murciélago Blanco. Quito: Publicación especial sobre los mamíferos del Ecuador 6. 576 pp.

Tirira, D. 2008. Mamíferos de los Bosques Húmedos del Noroccidente del Ecuador. Ediciones Murciélago Blanco. Quito: Publicación especial sobre los mamíferos del Ecuador 7.352 pp.

Tirira, D., S.F. Burneo and D. Valle. 2012a. Distribution extension of Chrotopterus auritus (Peters, 1856) (Chiroptera: Phyllostomidae) for southwestern Ecuador; pp. 195-200, in: D.G. Tirira and S.F. Burneo (eds.). Investigación y Conservación sobre Murciélagos en el Ecuador. Publicación especial sobre los mamíferos del Ecuador 9. Quito: Pontificia Universidad Católica del Ecuador, Fundación Mamíferos y Conservación and Asociación Ecuatoriana de Mastozoología.

Tirira, D.G., S.F. Burneo, K. Swing, J. Guerra and D. Valle. 2012b. Comentarios sobre la distribución de Amorphochilus schnablli Peters, 1877 (Chiroptera, Furipteridae) en Ecuador; pp. 209-216, in: D.G. Tirira and S.F. Burneo (ed.). Investigación y Conservación Sobre Murciélagos en el Ecuador. Publicación especial sobre los mamíferos del Ecuador 9. Quito: Pontificia Universidad Católica del Ecuador, Fundación Mamíferos y Conservación and Asociación Ecuatoriana de Mastozoología.

Trajano, E. 1982. New records of bats from southeastern Brazil. Journal of Mammalogy 63(3): 529 (doi: 10.2307/1380462).

Trujillo, G.F. and L. Albuja. 2005. Nuevos registros de Phylloderma stenops (Chiroptera: Phyllostomidae) y Lasiurus borealis (Chiroptera: Vespertilionidae) para el Ecuador. Politécnica 26(1): 45-53. (http:// bibdigital.epn.edu.ec/bitstream/15000/4011/1/Phylloderma\%20 stenops.pdf)

Williams, S.L. and H.H. Genoways. 2008 [2007]. Subfamily Phyllostominae Gray, 1825; pp. 255-300, in: A.L. Gardner (ed.). Mammals of South America. Volume I: Marsupials, Xenarthrans, Shrews, and Bats. Chicago and London: Chicago University Press.

York, H. 2008. Observations of frugivory in Phylloderma stenops (Chiroptera: Phyllostomidae). Caribbean Journal of Science 44(2): 257-260 (http://caribjsci.org/July08/44_257-260.pdf).

RECEIVED: May 2014

ACCEPTED: September 2014

PuBlished ONLINE: October 2014

EDITORIAL RESPONSIBILITY: Marcelo R. Nogueira 